\title{
Four RBSI Scholars Receive PhDs
}

A PSA is pleased to announce that four former APSA Ralph Bunche Summer Institute (RBSI) Scholars recently attained their $\mathrm{PhD}$.

Erin K. Melton (RBSI 2005) is an assistant professor in the department of public policy at the University of Connecticut. She earned her $\mathrm{PhD}$ from Texas A\&M University. Dr. Melton researches race and ethnic politics in public administration and public policy. She has published work assessing the ways organizations contend with contextual differences, such as diversity among employees or the presence of public managers who are racial or ethnic minorities.

Meredith Walker (RBSI 2006) is a postdoctoral fellow in the department of public administration and policy at American University. Her research focuses on the areas of race and public administration and management. She recently completed her dissertation "Assessing the Intersection of Race and Gender in Public Policy and Public Management: An Examination of African American Males in Education" at Texas A\&M University. Dr. Walker teaches a course on race, policy, and administration for MPA and MPP.

Eugene Walton (RBSI 2004) has accepted a postdoctoral fellowship at The Pennsylvania State University through the department of political science and the Africana Research Center (ARC). His research focuses on international security, armed non-state actors, and the politics of identity. Dr. Walton completed his $\mathrm{PhD}$ degree in the department of political science at Duke University and is a graduate fellow at The Center for the Study of Race Ethnicity and Gender in the Social Science (REGSS).

Michael H. Woldemariam (RBSI 2004) is an assistant professor of international relations and political science at Boston University. He recently completed his dissertation "Why Rebels Collide: Factionalism and Fragmentation in African Insurgencies" at Princeton University. His teaching and research interests include African politics, particularly the dynamics of armed conflict, the behavior of rebel organizations and self-determina- tion movements, and post-conflict institution building. He has a special expertise in the Horn of Africa, and has conducted fieldwork in Ethiopia, Mozambique, Somaliland, South Africa, and India. Dr. Woldermariam teaches the following courses: Africa on International Politics, Government and Politics of Contemporary Africa, as well as Conflict and State-Building in Africa.

The APSA Ralph Bunche Summer Institute was designed to encourage students to pursue academic careers in political science. The Ralph Bunche Summer Institute, created in 1986 , is an intensive 5 week academic and professional development program designed to assist in preparing students for graduate work in political science. The program provides academic credit, mentoring, and training in statistical analysis and the substantive area of race and ethnicity in political science. The program goal is to encourage students to pursue academic careers in political science. We are excited that this goal is being met. The Ralph Bunche Summer Institute is hosted and cosponsored by Duke University, under the direction of professor Paula D. McClain. The program is also supported by a grant from the National Science Foundation (NSF) and is considered an REU Social, Behavioral, and Economic Sciences Site. The APSA provides additional operational support and funding.

\section{ABOUT THE PROGRAM}

Named in honor of the 1950 Nobel Peace Prize winner and former APSA President, Ralph J. Bunche, the Ralph Bunche Summer Institute (RBSI) program goal is to encourage students to pursue academic careers in political science by helping to enhance participants' writing, research, and analytical skills and make them more competitive applicants for graduate school admissions and financial assistance; improve the students' use of computers for statistical analysis of research data used in the study of political science; expose interested and engaged students to issues in the discipline and profession of political science; introduce participants to leading political scientists; and inform promising students about political science career opportunities and encourage applications to $\mathrm{PhD}$ programs in political science.

Each summer, the Institute gives 20 students a look at the world of graduate study with a program of two transferable credit courses, one in quantitative analysis and one in race and American politics, to introduce the intellectual demands of graduate school and political science research methods. For a final project for both courses, students prepare original, empirical research papers, and top students are given the opportunity to present their research at APSA's Annual Meeting, with all expenses paid by the association.

Classes are held on the Duke University campus, where students have access to a fully equipped computer laboratory, library collections, and other university facilities. Educational activities range from formal classroom settings to informal dinners and lunches with prominent political scientists and Duke University faculty. A strong ethics component is included with readings, cases, debates, and lectures on issues within an academic setting.

Because good performance on the Graduate Record Exam (GRE) is key to admission to and funding for graduate school, GRE test-taking strategies are provided by Princeton Review.

At the end of the Institute, representatives from a number of leading $\mathrm{PhD}$-granting institutions come from across the country to participate in a recruitment fair. They visit with Bunche students, provide information about their doctoral programs, and discuss admissions concerns with the students.

The 2012 APSA RBSI Program runs from June 3, 2012 to July 4, 2012. The RBSI Recruitment Fair will take place at Duke University, on Friday, June 22, 2012. For more information on the fair, contact dcross@duke.edu.

Visit www.pasanet.org/content_6602. cfm?navID $=954$ or contact Shaunda Ragland, sragland@apsanet.org or 202.349.9362. 